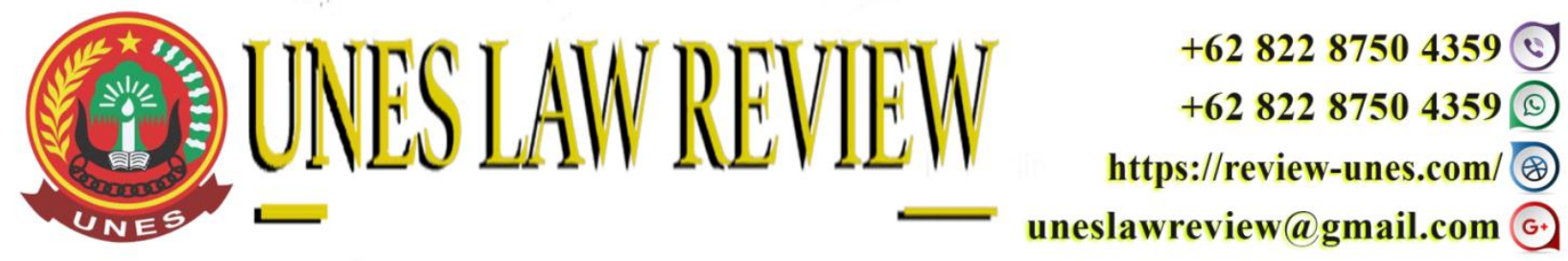

DOI: https://doi.org/10.31933/unesrev.v3i2

Diterima: 02/02/2021, Diperbaiki: 20/02/2021, Diterbitkan: 23/02/2021

\title{
PELAKSANAAN PUTUSAN TATA USAHA NEGARA DALAM PELANGGARAN ADMINISTRASI PEMILU BERDASARKAN PUTUSAN NO. 56/G/SPPU/2018/PTUN-JKT
}

\author{
Wisnu Nugraha \\ Fakultas Hukum, Universitas Krisnadwipayana, Bekasi, Indonesia \\ Email: nugraha.24.wn@gmail.com
}

Corresponding Author: Nugraha

\begin{abstract}
ABSTRAK
Penulisan ini disusun dalam tujuan untuk mempelajari dan meninjau pelaksanaan putusan tata usaha negara dalam pelanggaran adminisrasi pemilu berdasarkan Putusan No. 56/G/SPPU/2018/PTUN-JKT. Penelitian ini dibuat dalam metode literature kepustakaan dan menggunakan putusan sebagai objek penelitian Hasil yang diperoleh adalah preskriptif. Tujuan rumusan masalah penelitian ini adalah untuk (1) Bagaimana Putusan Nomor 56/G/SPPU/2018/PTUN-JKT atas Partai Politik PKP Indonesia dan (2) Mengapa Majelis mengabulkan permohonan Partai Politik PKP Indonesia. Kesimpulan yang diperoleh adalah (1) Bahwa putusan Nomor 56/G/SPPU/2018/PTUN-JKT memberikan kepastian hukum kepada PKP Indonesia sebagai partai politik untuk dapat ikut serta dalam kegiatan pemilu setelah memperoleh pemulihan hak akibat pelanggaran administratif yang dikeluarkan oleh KPU RI. (2) Bahwa pertimbangan majelis hakim PTUN Jakarta adalah memberikan pemahaman bahwa KPU RI harus dapat menjalankan tugas dna tanggungjawabnya sesuai dengan asas-asas hukum penyelenggaraan pemerintahan yang baik dimana keputusan yang ada yaitu keputusan MK tidak dapat meniadakan keputusan KPU RI sebelumnya terhadap hasil administratif dari PKP Indonesia yang sudah dinyatakan lolos dan dapat mengikuti tahap verifikasi factual berdasarkan Berita Acara Hasil Akhir Penelitian Administrasi Dokumen Persyaratan Partai Politik Calon Peserta Pemilu Tahun 2019 Nomor: 92/PL.01.1-BA/03/KPU/XII/2017 tertanggal 22 Desember 2017
\end{abstract}

\section{Kata Kunci: Partai Politik, Pemilu, KPU}

\section{PENDAHULUAN}

Adanya hukum di dunia adalah untuk mengatur kehidupan manusia menuju arah yang lebih baik. Hukum disusun, ditetapkan dan diberlakukan untuk dihormati, ditaati dan ditindaklajuti. Keberadaan hukum sangat berpengaruh kepada perkembangan kehidupan manusia, manusia tanpa hukum akan menimbulkan dinamika main hakim sendiri. Bila hal 
demikian terjadi maka kekacauan akan semakin bertambah. Putusan pengadilan merupakan satu dari sekian sumber hukum. Selain adanya Undang-Undang dan peraturan perundang-undangan yang ada di bawahnya. Putusan pengadilan menjadi sumber hukum dan kepastian yang menentukan siapa yang berhak dan siapa yang melanggar. Namun keberadaan putusan pengadilan bersifat represif, karena ada setelah masalah terjadi. Meski demikian putusan pengadilan yang seharusnya menjadi solusi bagi para pihak yang bersengketa tidak dapat langsung menjadi acuan yang dapat ditegakkan, sebab masih ada upaya hukum yang dapat menunda suatu putusan pengadilan untuk dapat dilaksanakan.

Hal ini juga terjadi di dalam Putusan PTUN No. 56/ G/SPPU/2018/PTUN-JKT. Dimana Partai Keadilan dan Persatuan Indonesia mengajukan gugatan kepada PTUN Jakarta terhadap KPU RI atas keluarnya Surat Keputusan Komisi Pemilihan Umum Republik Indonesia Nomor 58/PL.01.1-Kpt/03/KPU/II/2018, tanggal 17 Februari 2018 Tentang Penetapan Partai Politik Peserta Pemilihan Umum Anggota Dewan Perwakilan Rakyat, Dewan Perwakilan Rakyat Daerah Provinsi, dan Dewan Perwakilan Rakyat Daerah Kabupaten/Kota Tahun 2019, sepanjang pada Diktum Kedua huruf b yang pada pokoknya menetapkan Partai Keadilan dan Persatuan Indonesia tidak memenuhi syarat sebagai Peserta Pemilihan Umum Anggota Dewan Perwakilan Rakyat, Dewan Perwakilan Rakyat Daerah Provinsi, dan Dewan Perwakilan Rakyat Daerah Kabupaten/Kota Tahun 2019. Terbitnya surat keputusan ini jelas merugikan Partai Keadilan dan Persatuan Indonesia dalam hal konstitusionalnya untuk menjadi peserta pemilihan umum (pemilu).

Penulis akan membahas hal-hal seputar, yaitu mengenai:

1. Bagaimana Putusan Nomor 56/G/SPPU/2018/PTUN-JKT atas Partai Politik PKP Indonesia?

2. Mengapa Majelis mengabulkan permohonan Partai Politik PKP Indonesia?

\section{KERANGKA TEORI DAN KONSEP}

\section{W.F. Prins}

Beschiking adalah suatu tindakan hukum sepihak di bidang pemerintahan, dilakukan oleh alat penguasa berdasarkan kewenangan khusus (Kuntjoro Purbopranoto, 1978:46). Utrecht

Beschiking adalah suatu perbuatan berdasarkan hukum publik yang bersegi satu adalah yang dilakukan oleh alat-alat pemerintahan berdasarkan suatu kekuasaan istimewa. Van Poelje

Pernyataan tertulis kehendak suatu alat pemerintahan dari penguasa pusat yang sifatnya sepihak dan ditujukan ke luar, berdasarkan suatu kewenangan atas dasar satu peraturan hukum tata Negara atau hukum tata Pemerintahan dan yang tujuannnya ialah perubahan atau pembatalan sesuatu hubungan hukum yang ada atau penetapan suatu hubungan hukum yang baru ataupun yang memuat suatu penolakan pemerintah - penguasa terhadap hal tersebut.

\section{A.M. Donner}

Penetapan adalah tindakan pemerintahan dalam jabatan secara sepihak dan disengaja dalam suatu ikhwal tertentu, menetapkan suatu hubungan hukum atau suatu keadaan hukum 
yang sedang berjalan atau menimbulkan suatu hubungan hukum baru atau menolak salah satu yang dimaksud.

Sjachran Basah

Tujuan PTUN adalah untuk memberikan pengayoman hukum dan kepastian hukum, baik bagi rakyat maupun administrasi negara dalam arti terjaganya keseimbangan kepentingan masyarakat dengan kepentingan individu. Kepentingan administrasi negara berupa terjaganya ketertiban, ketentraman dan keamanan dalam pelaksanaan tugas-tugasnya, demi terwujudnya pemerintahan bersih dan berwibawa dalam kaitan negara hukum berdasarkan Pancasila (Sjachran Basah, 1985:154).

Rozali Abdullah

Hukum acara PTUN adalah rangkaian perturan-peraturan yang memuat cara bagaimana orang harus bertindak, satu sama lain untuk melaksanakan berjalannya peraturan Tata Usaha Negara. Pengaturan terhadap hukum formal dapat digolongkan menjadi dua bagian, yaitu:

1. Ketentuan prosedur berperkara diatur bersama-sama dengan hukum materiilnya peradilan dalam bentuk UU atau perturan lainnya.

2. Ketentuan prosedur berperkara diatur tersendiri masing-masing dalam bentuk UU atau bentuk peraturan lainnya (Abdulah, Rozzali, 2005).

Berdasarkan syarat-syarat keabsahan suatu Keputusan Tata Usaha Negara, mengutip pandangan Van der Wel membagi syarat-syarat tersebut menjadi dua golongan yakni (Tjandra, W. Riawan, 2005) :

1. Syarat-syarat materiil, meliputi:

a. Instansi/alat negara yang membuat Keputusan Tata Usaha Negara tersebut harus berwenang menurut jabatannya, baik kewenangan dalam lingkup wilayah hukumnya maupun kewenangan berdasarkan persoalanya.

b. Dalam kehendak alat negara yang membuat Keputusan Tata Usaha Negara tidak boleh ada kekurangan-kekurangan yuridis seperti kehilapan, penipuan, paksaan, dan penyogokan.

c. Keputusan Tata Usaha Negara harus berdasarkan suatu keadaan tertentu.

d. Keputusan Tata Usaha Negara tersebut harus dapat dilaksanakan dan tanpa melanggar peraturan-peraturan lain, menurut isi dan tujuan sesuai dengan peraturan-peraturan lain yang menjadi dasar Keputusan Tata Usaha Negara tersebut.

2. Syarat-syarat formil, meliputi:

a. Syarat-syarat yang ditentukan berkaitan dengan persiapan dan cara pembuatan suatu Keputusan Tata Usaha Negara.

b. Keputusan Tata Usaha Negara harus diberi bentuk yang ditentukan.

c. Syarat-syarat yang ditentukan berkaitan dengan pelaksanaan Keputusan Tata Usaha Negara.

d. Jangka waktu yang ditentukan antara timbulnya hal-hal yang menyebabkan dibuatnya suatu Keputusan Tata Usaha Negara dan pengumuman Keputusan Tata Usaha Negara itu tidak boleh dilewati. 


\section{HASIL DAN PEMBAHASAN}

\section{Gambaran Putusan Nomor 56/G/SPPU/2018/PTUN-JKT}

Dewan Pimpinan Nasional Partai Keadilan \& Persatuan Indonesia (DPN PKP Indonesia) melawan Komisi Pemilihan Umum Republik Indonesia. Pasal 1 ayat (3) Undang Undang Nomor 5 Tahun 1986 jo Undang Undang Nomor 9 Tahun 2004 tentang Peradilan Tata Usaha Negara, memuat ketentuan bahwa yang dimaksudkan dengan Keputusan Tata Usaha Negara adalah suatu penetapan tertulis yang dikeluarkan oleh Badan atau Pejabat Tata Usaha Negara yang berdasarkan peraturan perundang undangan yang berlaku, yang bersifat konkrit, individual dan final, yang menimbulkan akibat hukum bagi seseorang atau badan hukum perdata. Dikemukakan dalam penjelasan terhadap pasal ini bahwa, penetapan tertulis terutama menunjuk kepada isi dan bukan kepada bentuk keputusan yang dikeluarkan oleh Badan atau Pejabat Tata Usaha Negara. Keputusan tersebut memang diharuskan tertulis, namun yang disyaratkan tertulis bukanlah bentuk formalnya seperti surat keputusan pengangkatan dan sebagainya. Hal ini dimaksudkan untuk kemudahan dari segi pembuktiannya nanti sehingga, hanya dibutuhkan kejelasan soal, pertama Badan atau Pejabat Tata Usaha Negara yang mana yang mengeluarkannya; kedua, maksud serta mengenai hal apa isi tulisan tersebut dan ketiga, kepada siapa tulisan itu dituju dan apa yang ditetapkan didalamnya.

Dalam hal ini keputusan tata usaha negara yang dipermasalahkan adalah Surat Keputusan Komisi Pemilihan Umum Republik Indonesia Nomor 58/PL.01.1-Kpt/03/KPU/II/2018, tanggal 17 Februari 2018 Tentang Penetapan Partai Politik Peserta Pemilihan Umum Anggota Dewan Perwakilan Rakyat, Dewan Perwakilan Rakyat Daerah Provinsi, dan Dewan Perwakilan Rakyat Daerah Kabupaten/Kota Tahun 2019, sepanjang pada Diktum Kedua huruf b yang pada pokoknya menetapkan Partai Keadilan dan Persatuan Indonesia tidak memenuhi syarat sebagai Peserta Pemilihan Umum Anggota Dewan Perwakilan Rakyat, Dewan Perwakilan Rakyat Daerah Provinsi, dan Dewan Perwakilan Rakyat Daerah Kabupaten/Kota Tahun 2019.

\section{Legal Standing Partai Keadilan \& Persatuan Indonesia}

Partai Keadilan \& Persatuan Indonesia (PKP INDONESIA) menjadi Pihak Penggugat dalam perkara ini merupakan partai politik calon peserta Pemilihan Umum Tahun 2019 yang telah mengikuti verifikasi administrasi dan faktual yang berdasarkan Keputusan KPU RI dinyatakan tidak memenuhi syarat sehingga merasa kepentingannya dirugikan. Kerugian PKP Indonesia adalah nyata, mengingat sebagai sebuah partai politik yang didirikan secara sah berdasarkan hukum Republik Indonesia dinyatakan tidak memenuhi syarat untuk ikut dalam Pemilihan Umum 2019. Padahal, partai politik didirikan dengan tujuan untuk meraih kekuasaan politik. Dengan dinyatakan tidak memenuhi syarat untuk ikut sebagai peserta dalam Pemilihan Umum 2019, maka segala energi, dana dan waktu yang dicurahkan sejak Pemilihan Umum Tahun 2014 dalam mempersiapkan partai untuk mengikuti Pemilihan Umum berikutnya, menjadi sia-sia belaka adapun bentuk bentuk kerugian yang diderita PKP Indonesia akibat Keputusan KPU RI sebagai berikut: 
1. Bahwa PKP Indonesia adalah salah satu Partai Politik yang hidup dan berkembang di Negara Kesatuan Republik Indonesia yang sejak berdirinya tahun 1999 dan telah beberapa kali menjadi peserta Pemilihan Umum, pada Pemilu 1999, PKP Indonesia cq. PKP Indonesia memperoleh 1.065.810 suara, 4 kursi DPR, 26 kursi DPRD Propinsi, dan 178 kursi DPRD Kabupaten/Kota; Pemilu 2004, PKP INDONESIA mendapat 1.424 .240 suara dan meraih satu kursi DPR; Pemilu 2009, PKP INDONESIA memperoleh 934.892 suara memperoleh 11 kursi DPRD Propinsi dan memperoleh 195 kursi DPRD Kabupaten/Kota;

Hal ini menunjukkan bahwa PKP Indonesia juga berperan menghidupkan demokrasi tingkat lokal dengan selalu mengikuti Pemilihan Kepala Daerah dan Wakil Kepala Daerah (Pilkada);

2. Bahwa PKP Indonesia memiliki anggota Dewan Perwakilan Rakyat Daerah Propinsi (DPRD Propinsi) dan Dewan Perwakilan Rakyat Daerah Kabupaten/Kota (DPRD Kabupaten/Kota) dan masih berperan untuk kepentingan Bangsa dan Negara khususnya menyuarakan dan menjalankan kepercayaan Pemilih;

3. Bahwa bahkan dalam Penyelenggaraan Pemilu tahun 2019 PKP Indonesia (In casu PKP INDONESIA) telah terdaftar sebagai Calon Peserta Pemilu di KPU dan telah pula mengikuti serangkaian proses tahapan Pemilu yang dilaksanakan oleh KPU sampai dengan tahap rekapitulasi nasional hasil verifikasi partai politik calon Peserta Pemilu 2019;

4. Bahwa dengan terbitnya Surat Keputusan KPU RI (Obyek Gugatan) dengan sengaja untuk menghalang-halangi dan/atau menghilangkan hak konstitusi warga negara yakni hak memilih partai politik, anggota partai politik, hak memilih dan hak untuk dipilih yang dijamin Undang-Undang Dasar Tahun 1945 pasal 28 E

"Setiap orang berhak atas kebebasan berserikat berkumpul dan mengeluarkan pendapat ";

5. Bahwa dengan demikian atas terbitnya Obyek Sengketa yang dikeluarkan KPU RI telah merugikan PKP Indonesia tidak dapat menjadi peserta pemilu pada tahun 2019, padahal telah pula mengikuti serangkaian proses tahapan Pemilu yang dilaksanakan oleh KPU sampai dengan tahap rekapitulasi nasional hasil verifikasi partai politik calon Peserta Pemilu 2019;

Bahwa Keputusan KPU RI yang menyatakan PKP Indonesia tidak memenuhi syarat untuk ikut dalam Pemilihan Umum 2019 dan ditolak oleh PKP Indonesia selaku calon Peserta Pemilu, telah melahirkan "sengketa tata usaha negara Pemilu" sebagaimana didefinisikan oleh Pasal 470 ayat (2) huruf a Undang-Undang Nomor 7 Tahun 2017 tentang Pemilu, yakni PKP Indonesia, sebagai calon Peserta Pemilu yang telah menjalani verifikasi administratif dan faktual dan dinyatakan tidak lolos oleh KPU RI.

\section{Kualifikasi Kewenangan Pengadilan Tata Usaha Negara}

Dengan demikian, berdasarkan Pasal 469 ayat (2) Undang-Undang Nomor 7 Tahun 2017 tentang Pemilu jo. Pasal 1 angka 8 Peraturan Mahkamah Agung Republik Indonesia Nomor 5 Tahun 2017 adalah pihak yang mempunyai kedudukan hukum atau "legal standing" untuk mengajukan gugatan sengketa proses pemilu ini langsung ke Pengadilan Tata Usaha Negara.

Bahwa sebelum mengajukan gugatan ke Pengadilan Tata Usaha Negara, PKP Indonesia telah mengajukan upaya administratif kepada Bawaslu untuk menyelesaikan sengketanya dengan 
KPU RI. Namun Keputusan Bawaslu Nomor 012/PS-REG2/BAWASLU/II/2018 tanggal 6 Maret 2018 telah menolak keberatan-keberatan yang diajukan PKP Indonesia terhadap Putusan KPU RI dan dengan demikian sungguh tidak memuaskan PKP Indonesia.

Dengan selesainya seluruh upaya administratif di Bawaslu, maka selanjutnya Pengadilan Tata Usaha Negara berwenang untuk memeriksa, mengadili dan memutus gugatan ini sebagaimana diatur dalam Ketentuan pasal 471 ayat (1) Undang-Undang Nomor 7 Tahun 2017 tentang Pemilihan Umum, jo Pasal 2 ayat (2) Peraturan Mahkamah Agung Nomor 5 Tahun 2017 tentang Tata Cara Penyelesaian Sengketa Proses Pemilihan Umum di Pengadilan Tata Usaha Negara;

Bahwa oleh karena Putusan Bawaslu mengenai sengketa Pemilu yang berkaitan dengan verifikasi Partai Politik Peserta Pemilu bukan merupakan putusan final sebagaimana diatur dalam Pasal 469 ayat (2) Undang-Undang Nomor 7 Tahun 2017 tentang Pemilu, maka PKP Indonesia yang merasa kepentingannya dirugikan dengan Keputusan KPU RI "dapat mengajukan guugatan tertulis kepada pengadilan Tata Usaha Negara".

Selanjutnya norma Pasal 471 ayat (1) Undang-Undang Nomor 7 Tahun 2017 tentang Pemilihan Umum dengan jelas menyebutkan bahwa Pengadilan Tata Usaha Negara berwenang untuk memeriksa, mengadili dan memutus gugatan ini.

\section{Kronologis Perkara}

Bahwa PKP Indonesia telah mendaftar sebagai Partai Politik peserta Pemilu 2019 dan dinyatakan telah lolos penelitian administrasi untuk selanjutnya dilakukan verifikasi faktual berdasarkan Berita Acara Hasil Akhir Penelitian Administrasi Dokumen Persyaratan Partai Politik Calon Peserta Pemilu Tahun 2019 Nomor: 92/PL.01.1-BA/03/KPU/XII/2017 tertanggal 22 Desember 2017;

Bahwa Bawaslu telah menyurati KPU RI dengan surat Nomor: 0890/Bawaslu/PM.00.00/IX/2017 tertanggal 29 September 2017, perihal Pelaksanaan pendaftaran dan penelitian administrasi partai politik calon peserta pemilu 2019, dan terhadap surat tersebut telah dijawab/ditindaklajuti oleh KPU RI dengan surat Nomor: 569/PL.01.1SD/03/KPU/X2017 tertanggal 2017;

Bahwa PKP Indonesia telah mengajukan laporan kepada Bawaslu terkait pelanggaran administrasi Pemilu yang dilakukan KPU RI terkait tata cara dan prosedur pendaftaran melalui Sistem Informasi Partai Politik (SIPOL), dan telah diputus Bawaslu dalam Putusan Nomor: 001/ADM/BWSL/ PEMILU/X/2017 tertanggal 15 Nopember 2017;

Bahwa PKP Indonesia setelah dinyatakan lolos pada tahap penelitian administrasi, selanjutnya akan dilakukan verifikasi faktual terhadap daerah otonom baru yang belum memenuhi syarat sebagaimana ketentuan Pasal 173 ayat (2) huruf b dan huruf c Undang-Undang Nomor 7 Tahun 2017 Tentang Pemilihan Umum;

Bahwa pada saat tahapan pemilu sedang berjalan yaitu pada tahapan pendaftaran dan verifikasi peserta pemilu terbitnya Putusan Mahkamah Konstitusi Nomor: 53/PUU-XV/2017 tertanggal 11 Januari 2018, tentang pengujian tentang Pasal 173 ayat (1) dan ayat (3) Undang- 
Undang Pemilu 2019, yang pada pokoknya di halaman 20 putusan tersebut berbunyi "Dalil pemohon agar frasa "telah ditetapkan/" dalam Pasal 173 ayat (1) dan seluruh norma dalam Pasal 173 ayat (3) UU Pemilu dinyatakan bertentangan dengan UUD 1945 dan tidak mempunyai kekuatan hukum mengikat adalah beralasan hukum;"

Bahwa kemudian pasca atau setelah terbitnya Putusan Mahkamah Konstistusi tersebut, KPU RI menerbitkan 2 (dua) Peraturan Komisi Pemilihan Umum yang baru yaitu Peraturan Komisi Pemilihan Umum Republik Indonesia Nomor 5 Tahun 2018 Tentang Perubahan atas Peraturan Komisi Pemilihan Umum Nomor 7 Tahun 2017 Tentang Tahapan, Program, Dan Jadwal Penyelenggaraan Pemilihan Umum Tahun 2019, dan juga Peraturan Komisi Pemilihan Umum Republik Indonesia Nomor 6 Tahun 2018 Tentang Pendaftaran, Verifikasi, Dan Penetapan Partai Politik Peserta Pemilihan Umum Anggota Dewan Perwakilan Rakyat Dan Dewan Perwakilan Rakyat Daerah

Bahwa kemudian KPU RI melanjutkan tahapan kegiatan Pemilu yaitu Penelitian administrasi dan verifikasi faktual terhadap PKP Indonesia, dan disimpulkan dalam Berita Acara Rekapitulasi di masing-masing KPU Provinsi dan KPU Kabupaten/Kota;

Bahwa di beberapa daerah/kabupaten kepengurusan PKP Indonesia telah membuat surat pernyataan yang pada pokoknya tidak sanggup/memenuhi beberapa persyaratan terkait penelitian administrasi, verifikasi dan juga tidak sanggup menghadirkan anggota partai sebagaimana yang tercantum dalam Sistem Informasi Partai Politik;

Bahwa pada akhirnya PKP Indonesia telah dinyatakan Tidak Memenuhi Syarat sebagai peserta Pemilu Tahun 2019 dan PKP Indonesia telah melakukan proses penyelesaian sengketa proses pemilu melalui Bawaslu terhadap terbitnya objek sengketa;

\section{Pertimbangan Majelis Hakim PTUN}

Terdapat dua sudut pandang dalam menilai sahnya suatu Keputusan Tata Usaha Negara yakni dari sudut pandang doktrin dan normatif. Ditinjau dari sudut pandang doktrin, menurut Van der Pot, sebagaimana dikutip oleh Tjandra, ada 4 (empat) syarat sahnya suatu Keputusan Tata Usaha Negara, yakni:

1. Keputusan Tata Usaha Negara harus dibuat oleh alat (organ) yang berwenang (bevoegd) untuk membuatnya.

2. Oleh karena Keputusan Tata Usaha Negara merupakan suatu pernyataan kehendak (wilsverklaring), maka pembentukan kehendak tersebut tidak boleh mengandung kekurangan yuridis (geen juridisce gebreken in de wilsvorming) yakni tidak boleh mengandung paksaan, kekeliruan dan penipuan.

3. Keputusan Tata Usaha Negara harus diberi bentuk (vorm) yang ditetapkan dalam peraturan yang menjadi dasarnya dan pembuatannya harus memperhatikan cara atau prosedur pembuatan Keputusan Tata Usaha Negara itu, manakalah cara itu ditetapkan dengan tegas dalam peraturan dasar tersebut.

4. Isi dan tujuan Keputusan Tata Usaha Negara harus sesuai dengan isi dan tujuan peraturan dasarnya. 
Menimbang, bahwa terhadap seluruh fakta hukum yang terurai diatas Majelis Hakim akan menguji dari segi yuridis (rechtmatigeheid) karena setiap tindakan pejabat tata usaha negara/KPU RI harus berdasarkan asas legalitas atau asas rechmatigheid van bestuur yaitu setiap tindakan pemerintahan atau pejabat tata usaha negara harus berdasarkan atas hukum atau peraturan perundang-undangan yang berlaku dan juga telah bersesuaian dengan Asas Asas Umum pemerintahan yang baik, sebagai berikut:

Menimbang, bahwa berdasarkan fakta hukum yang telah terurai diatas yaitu bahwa KPU RI telah menerbitkan Berita Acara Hasil Akhir Penelitian Administrasi Dokumen Persyaratan Partai Politik Calon Peserta Pemilu 2019 Nomor: 92/PL.01.1-BA/03/KPU/XII/2017 tertanggal 22 Desember 2017 yang pada pokoknya menyatakan bahwa PKP Indonesia telah Memenuhi Syarat atau lulus tahapan penelitian administrasi dan selanjutnya dilakukan verifikasi faktual dan Surat Keputusan Komisi Pemilihan Umum Republik Indonesia Nomor: 232/PL.01.1Kpt/03/KPU/XII/2017 Tertanggal 22 Desember 2017 Tentang Perubahan Atas Keputusan Komisi Pemilihan Umum Nomor: 227/PL.01.1-Kpt/03/KPU/XII/2017 Tentang Kedudukan Partai Politik Peserta Pemilu Tahun 2014 Pada Daerah Otonom Baru Dalam Pemenuhsan Persyaratan Partai Politik Peserta Pemilu 2019, yang pada pokoknya memutuskan PKP Indonesia untuk memenuhi kekurangan persyaratan di beberapa Daerah Otonom Baru, namun terjadi perubahan tahapan penyelenggaraan Pemilu di karenakan terbit/lahirnya Putusan Mahkamah Konstitusi Nomor: 53/PUU-XV/2017 tertanggal 11 Januari 2018, yang pada pokoknya menguji/memutuskan yaitu dalil Pemohon agar frasa "telah ditetapkan/" dalam Pasal 173 ayat (1) dan seluruh norma dalam Pasal 173 ayat (3) UU Pemilu dinyatakan bertentangan dengan UUD 1945 dan tidak mempunyai kekuatan hukum mengikat adalah beralasan menurut hukum, maka terhadap Putusan Mahkamah Konstitusi tersebut Majelis Hakim memaknai bahwa seluruh Partai Politik Calon Peserta Pemilu 2019 baik yang lama maupun yang baru harus dilakukan Verifikasi dikarenakan Putusan Mahkamah Konstitusi tersebut bersifat final dan mengikat (final and binding).

Hal ini berarti yang mempunyai makna bahwa putusan tersebut langsung memperoleh kekutan hukum tetap sejak diucapkan dan tidak ada upaya hukum yang dapat di tempuh, serta mengikat artinya tidak hanya berlaku bagi para pihak tetapi bagi seluruh masyarakat Indonesia, kemudian juga harus dipahami bahwa Putusan Mahkamah Konstitusi tersebut mempunyai sifat pemberlakuan non retroaktif artinya tidak berlaku surut atau berlaku prospektif ke depan hal ini diatur dalam ketentuan Pasal 47 Undang-Undang Nomor 24 Tahun 2003 Tentang Mahkamah Konstitusi dan juga di dalam Putusan Mahkamah Kostitusi tersebut tidak memuat frasa "retroaktif" atau berlaku surut.

Dengan demikian bahwa tindakan KPU RI yaitu menerbitkan Peraturan KPU terkait pemberlakuan verifikasi terhadap seluruh Partai Politik Calon Peserta Pemilu 2019 sudah sesuai dengan asas kepastian hukum khususnya terhadap satu putusan, namun KPU RI harus menyadari dan mempunyai konsekuensi hukum terhadap produk atau tindakan hukum yang telah atau terlanjur diterbitkan. 
Hal ini yaitu Berita Acara Hasil Akhir Penelitian Administrasi Dokumen Persyaratan Partai Politik Calon Peserta Pemilu 2019 Nomor: 92/PL.01.1-BA/03/KPU/XII/2017 tertanggal 22 Desember 2017 dan Surat Keputusan Komisi Pemilihan Umum Republik Indonesia Nomor: 232/PL.01.1-Kpt/03/KPU/XII/2017 Tertanggal 22 Desember 2017 Tentang Perubahan Atas Keputusan Komisi Pemilihan Umum Nomor: 227/PL.01.1-Kpt/03/KPU/XII/2017 Tentang Kedudukan Partai Politik Peserta Pemilu Tahun 2014 Pada Daerah Otonom Baru Dalam Pemenuhan Persyaratan Partai Politik Peserta Pemilu 2019.

Oleh karena tidak ada 1 (satu) bukti pun dalam persidangan yang menyatakan bahwa sampai dengan terbitnya objek sengketa kedua produk/tindakan hukum administrasi KPU RI tersebut telah dinyatakan batal oleh Pengadilan atau dinyatakan tidak berlaku atau dicabut oleh KPU RI sendiri sesuai Asas Contrarius Actus yaitu asas ini mempunyai makna Badan atau Pejabat Tata Usaha Negara yang menerbitkan keputusan Tata Usaha Negara dengan sendirinya juga berwenang untuk membatalkannya, dan juga setelah Majelis Hakim mencermati objek sengketa khususnya dalam konsideran "Memperhatikan" tidak mencantumkannya kedua produk I tindakan hukum administrasi KPU RI tersebut adalah tindakan yang tidak konsisten dan melanggar ketentuan Pasal 3 huruf d dan e yang pada pokoknya berbunyi Penyelenggara Pemilu atau KPU RI harus memenuhi prinsip berkepastian hukum dan tertib, selain itu juga KPU RI melanggar asas kepercayaan dan menanggapi pengharapan yang wajar, dimana asas ini menghendaki agar setiap tindakan yang dilakukan oleh pemerintah harus menimbulkan harapanharapan bagi warga negara. Jika suatu harapan sudah terlanjur diberikan kepada warga negara tidak boleh ditarik kembali meskipun tidak menguntungkan bagi pemerintah (Ridwan HR, Hukum administrasi Negara, edisi revisi, Rajawali Pers 2011), hal ini juga sejalan dengan keterangan Ahli dalam persidangan yaiu Prof Dr. HM. Laica Marzuki, S.H. M.H.;

Menimbang, bahwa selanjutnya Majelis Hakim akan memberi penilaian hukum terhadap tahapan verifikasi yang telah dilakukan KPU RI terhadap PKP Indonesia pasca/setelah adanya putusan Mahkamah Konstitusi Nomor: 53/PUU-XV/2017 tertanggal 11 Januari 2018, apakah telah sesuai dengan ketentuan hukum yang berkaitan terhadap hal tersebut yaitu Undang-Undang Pemilu 2019, Peraturan Komisi Pemilihan Umum Republik Indonesia Nomor 5 Tahun 2018 Tentang Perubahan atas Peraturan Komisi Pemilihan Umum Nomor 7 Tahun 2017 Tentang Tahapan, Program, Dan Jadwal Penyelenggaraan Pemilihan Umum Tahun 2019, dan juga Peraturan Komisi Pemilihan Umum Republik Indonesia Nomor 6 Tahun 2018 Tentang Pendaftaran, Verifikasi, Dan Penetapan Partai Politik Peserta Pemilihan Umum Anggota Dewan Perwakilan Rakyat Dan Dewan Perwakilan Rakyat Daerah, maka dari itu Majelis Hakim akan menguji secara komulatif terhadap daerah daerah kepengurusan PKP yang dinyatakan Tidak Memenuhi Syarat yakni 73 (tujuh puluh tiga) Kabupaten/Kota di 4 (empat) Provinsi sebagai berikut:

Menimbang, bahwa setelah mencermati bukti surat KPU RI yaitu Berita Acara Rekapitulasi Nasional Hasil Penelitian Administrasi Dan Verifikasi Kepengurusan, Keterwakilan Perempuan, Domisili Kantor Keanggotaan Partai Politik Calon Peserta Pemilu Nomor: 21/PL.01.1-BA/KPU/II/2018 tertanggal 17 Februari 2018 yang merupakan salah satu pedoman 
KPU RI pada saat menerbitkan objek sengketa, maka Majelis Hakim akan mencermati daerah yang dinyatakan Tidak Memenuhi Syarat sebagai berikut:

Menimbang, bahwa terhadap Provinsi Jawa Barat yang telah dilakukan verifikasi oleh KPU RI setelah Majelis Hakim mencermati salah satunya terhadap Kabupaten Garut di dalam Berita Acara Verifikasi Faktual Kepengurusan, Keterwakilan Perempuan, Domisili Kantor, Dan Keanggotaan Partai Politik Calon Peserta Pemilu Tingkat Kabupaten Garut, dalam lampiran disebutkan Belum Memenuhi syarat dan khususnya dalam kolom keterangan tertulis tidak sesuai dengan di SIPOL dan

Berita Acara Verifikasi Faktual Kepengurusan, Keterwakilan Perempuan, Domisili Kantor, Dan Keanggotaan Partai Politik Calon Peserta Pemilu Tingkat Kabupaten Indramayu dalam lampiran disebutkan Belum Memenuhi syarat dan khususnya dalam kolom keterangan tertulis tidak sesuai dengan di SIPOL, maka berdasarkan fakta hukum tersebut terbukti bahwa KPU RI yaitu KPU Kabupaten/Kota tetap berpedoman kepada Sistem Informasi Partai Politik, padahal terhadap permasalahan SIPOL tersebut telah dijawab oleh Bawaslu dalam Putusannya Putusan Nomor: 001/ADM/BWSL/PEMILU/X/2017 tertanggal 15 Nopember 2017, yang pada pokoknya memutuskan bahwa:

1. Menyatakan KPU RI telah melakukan pelanggaran administrasi tata cara dan prosedur pendaftaran partai politik peserta pemilu;

2. Memerintahkan KPU memperbaiki tata cara dan prosedur pendaftaran PKPI dengan menerima dokumen pendaftaran sesuai ketentuan Pasal 176 dan Pasal 177 Undang-Undang Nomor 7 Tahun 2017 Tentang Pemilihan Umum;

3. Memerintahkan KPU RI untuk melakukan pemeriksaan kelengkapan dokumen persyaratan pendaftaran PKPI secara fisik;

4. Memerintahkan kepada KPU RI untuk melaksanakan Putusan ini paling lambat (3) hari kerja sejak pembacaan putusan dibacakan;

Maka terhadap putusan tersebut seharusnya dipatuhi oleh KPU RI selaku penyelenggara Pemilu bahwa Sipol bukan merupakan syarat utama dalam pendaftaran dan melakukan verifikasi, tindakan KPU RI dalam hal ini KPU Kabupaten Indramayu sebagaimana fakta tersebut diatas adalah tindakan KPU RI yang melanggar ketentuan Pasal 14 huruf J UndangUndang Pemilu 2019 yang pada pokoknya berbunyi bahwa KPU berkewajiban melaksanakan putusan Bawaslu mengenai sanksi atas pelanggaran administratif dan sengketa proses pemilu

Menimbang, bahwa selanjutnya Majelis Hakim akan memberi penilaian hukum terhadap tindakan KPU RI yaitu Setelah mencermati bukti KPU RI yang termuat dalam Berita Acara Nomor: 18/PL.01.1-BA/3203/KPUKab/II/2018 Berita Acara rekapitulasi hasil penelitian administrasi dan verifikasi kepengurusan, keterwakilan perempuan, domisili kantor, dan keanggotaan partai politik calon peserta pemilu yang pada pokoknya telah menyatakan secara keseluruhan bahwa PKP Indonesia di kabupaten Cianjur Memenuhi Syarat dan kemudian dalam Berita Acara Nomor: 19/PL.01.1-BA/3203/KPU-Kab/II/2018 Tentang Ralat rekapitulasi hasil administrasi dan verifikasi keanggotaan partai politik calon peserta pemilu untuk Partai Keadilan dan Persatuan Indonesia (PKP Indonesia), KPU RI mengubah/meralat menjadi Tidak memenuhi 
Syarat dan menyerahkannya kepada PKP Indonesia yang diterima pada tanggal 13 Februari 2018.

Terhadap fakta hukum tersebut terbukti bahwa KPU RI telah melampaui batas waktu yang diatur dalam Peraturan Komisi Pemilihan Umum Republik Indonesia Nomor 5 Tahun 2018 Tentang Perubahan atas Peraturan Komisi Pemilihan Umum Nomor 7 Tahun 2017 Tentang Tahapan, Program, Dan Jadwal Penyelenggaraan Pemilihan Umum Tahun 2019 khususnya yang telah termuat dalam lampiran peraturan tersebut, maka KPU RI patut dianggap telah melanggar ketentuan Pasal 20 huruf a Undang-Undang Pemilu 2019 yang pada pokoknya berbunyi bahwa KPU Kabupaten/Kota berkewajiban melaksanakan semua tahapan penyelenggaraan Pemilu dengan tepat waktu, selain itu juga KPU RI melanggar Asas-Asas Umum Pemerintahan yang Baik, khususnya Asas kecermatan yang pada pokoknya asas ini menghendaki agar badan / pejabat tata usaha negara senantiasa bertindak secara hati-hati agar tidak menimbulkan kerugian bagi masyarakat (Dr. S.F. Marbun, S.H.,M.Hum, Peradilan Administrasi Negara dan Upaya Administratif di Indonesia, cetakan ketiga (revisi), FH UII Press Juni 2011).

Menimbang, bahwa terkait fakta hukum di beberapa daerah/kabupaten di Provinsi Jawa Tengah kepengurusan PKP Indonesia telah membuat surat pernyataan yang pada pokoknya tidak sanggup/memenuhi beberapa persyaratan terkait penelitian administrasi, verifikasi dan juga tidak sanggup menghadirkan anggota partai sebagaimana yang tercantum dalam Sistem Informasi Partai Politik, terungkap fakta dalam persidangan baik dari saksi PKP Indonesia maupun saksi KPU RI bahwa surat pernyataan tersebut benar di tanda tangani oleh para pengurus di partai PKP Indonesia, namun inisiatif pembuatan surat keterangan tersebut muncul dari pihak KPU RI, terhadap hal tersebut Majelis Hakim berkesimpulan bahwa tindakan KPU RI tersebut melanggar ketentuan Pasal 3 huruf g dan h Undang-Undang Pemilu 2019 yang pada pokoknya mengamanatkan Penyelenggaraan harus memenuhi prinsip proporsional dan profesional, walaupun KPU RI mendalilkan bahwa pada pokoknya tindakan tersebut tidak menyalahi ketentuan peraturan perundangundangan;

Menimbang, bahwa setelah Majelis Hakim mempertimbangkan 3 (tiga) daerah yang telah dilakukan verifikasi dan ternyata terdapat pelanggaran ketentuan hukum, maka selanjutnya Majelis Hakim akan memberi penilaian hukum terhadap hasil akhir dari tindakan/keputusan yang diterbitkan yaitu Surat Keputusan objek sengketa a quo, setelah mencermati objek sengketa dapat disimpulkan bahwa yang menjadi salah satu dasar pedoman KPU RI menerbitkan objek sengketa adalah Berita Acara Rekapitulasi Nasional Hasil Penelitian Administrasi Dan Verifikasi Kepengurusan, Keterwakilan Perempuan, Domisili Kantor Keanggotaan Partai Politik Calon Peserta Pemilu Nomor: 21/PL.01.1-BA/KPU/II/2018 tertanggal 17 Februari 2018, bahwa di dalam Berita acara tersebut khususnya dalam lampiran untuk Provinsi Jawa Timur yaitu pada Kabupaten Jombang dalam kolom status tertulis TMS atau Tidak Memenuhi Syarat, hal ini berbanding terbalik atau tidak sama dengan fakta hukum yang sebenarnya yaitu dalam Berita Acara Rekapitulasi hasil Penelitian Administrasi dan verifikasi Faktual kepengurusan, keterwakilan perempuan, domisili kantor, dan keanggotaan partai politik calon peserta pemilu Provinsi Jawa Timur Kabupaten Jombang Nomor: 15/PL.03.6- BA/02/KPU /II/2018 beserta 
lampiran Model F.A.REKAP.KPU.KAB/KOTAPARPOL, dimana dalam Berita Acara tersebut yang diterbitkan berdasarkan Berita Acara sebelumnya tertulis dengan jelas dan tegas bahwa PKP Indonesia Memenuhi Syarat secara keseluruhan di Kabupaten Jombang.

Maka berdasarkan uraian fakta hukum tersebut Majelis Hakim berkesimpulan bahwa KPU RI telah melanggar Pasal 3 Undang-Undang Pemilu 2019 dan juga melanggar Asas-Asas Umum Pemerintahan yang Baik, khususnya Asas kecermatan yang pada pokoknya asas ini menghendaki agar badan/pejabat tata usaha negara senantiasa bertindak secara hati-hati agar tidak menimbulkan kerugian bagi masyarakat (Dr. S.F.Marbun, S.H.,M.Hum, Peradilan Administrasi Negara dan Upaya Administratif di Indonesia, cetakan ketiga (revisi), FH UII Press Juni 2011);

Menimbang, berdasarkan pertimbangan hukum diatas, Majelis Hakim berpendapat bahwa patut secara hukum menyatakan terdapat tahapan/prosedur yang tidak dilakukan atau tidak sempurna dilakukan oleh KPU RI dalam penerbitan Surat Keputusan Objek Sengketa sepanjang pada Diktum kedua huruf b yang pada pokoknya menetapkan Partai Keadilan dan Persatuan Indonesia tidak memenuhi syarat sebagai peserta Pemilihan Umum Anggota Dewan Perwakilan Rakyat, Dewan Perwakilan Rakyat Daerah Provinsi, dan Dewan Perwakilan Rakyat Daerah Kabupaten/Kota Tahun 2019, sehingga penerbitan Surat Keputusan objek sengketa cacat yuridis dari segi prosedural;

Menimbang, bahwa oleh karena penerbitan objek sengketa telah diterbitkan bertentangan dengan peraturan perundang-undangan yang berlaku dan asas-asas umum pemerintahan yang baik, sehingga harus dinyatakan batal, maka gugatan PKP Indonesia patut secara hukum untuk dikabulkan;

Menimbang, bahwa oleh karena gugatan PKP Indonesia telah dikabulkan untuk seluruhnya, maka pihak KPU RI berdasarkan ketentuan Pasal 110 dan Pasal 112 UndangUndang Peraturan harus dihukum untuk membayar biaya perkara yang jumlahnya akan tercantum dalam amar putusan ini; Mengingat, ketentuan dalam Undang-Undang Nomor 7 Tahun 2017 Tentang Pemilihan Umum, Undang-Undang Nomor 5 tahun 1986 sebagaimana telah diubah dengan Undang-Undang Nomor 9 Tahun 2004 dan UndangUndang Nomor 51 Tahun 2009, Peraturan Komisi Pemilihan Umum Republik Indonesia Nomor 5 Tahun 2018 Tentang Perubahan atas Peraturan Komisi Pemilihan Umum Nomor 7 Tahun 2017 Tentang Tahapan, Program, Dan Jadwal Penyelenggaraan Pemilihan Umum Tahun 2019, Peraturan Komisi Pemilihan Umum Republik Indonesia Nomor 6 Tahun 2018 Tentang Pendaftaran, Verifikasi, Dan Penetapan Partai Politik Peserta Pemilihan Umum Anggota Dewan Perwakilan Rakyat Dan Dewan Perwakilan Rakyat Daerah dan Peraturan Mahkamah Agung Republik Indonesia Nomor 5 Tahun 2017 Tentang Tata Cara Penyelesaian Sengketa Proses Pemilihan Umum Di Pengadilan Tata Usaha Negara, serta Peraturan-peraturan lain yang berkaitan; 


\section{Hasil Putusan PTUN}

Mengadili:

Dalam Eksepsi:

- Menyatakan eksepsi KPU RI tentang dalil-dalil gugatan PKP Indonesia tidak jelas dan/atau kabur (Obscuur Libel) tidak diterima;

Dalam Pokok Perkara:

1. Mengabulkan Gugatan PKP Indonesia Untuk Seluruhnya;

2. Menyatakan Batal Surat Keputusan Komisi Pemilihan Umum Republik Indonesia Nomor: 58/PL.01.1-Kpt/03/KPU/II/2018 tanggal 17 Februari 2018 Tentang Penetapan Partai Politik Peserta Pemilihan Umum Anggota Dewan Perwakilan Rakyat, Dewan Perwakilan Rakyat Daerah Provinsi, dan Dewan Perwakilan Rakyat Daerah Kabupaten/Kota Tahun 2019, sepanjang pada Diktum kedua huruf b yang pada pokoknya menetapkan Partai Keadilan dan Persatuan Indonesia tidak memenuhi syarat sebagai peserta Pemilihan Umum Anggota Dewan Perwakilan Rakyat, Dewan Perwakilan Rakyat Daerah Provinsi, dan Dewan Perwakilan Rakyat Daerah Kabupaten / Kota Tahun 2019;

3. Memerintahkan KPU RI untuk mencabut Surat Keputusan Komisi Pemilihan Umum Republik Indonesia Nomor 58/PL.01.1-Kpt/03/KPU/ II/2018 tanggal 17 Februari 2018 Tentang Penetapan Partai Politik Peserta Pemilihan Umum Anggota Dewan Perwakilan Rakyat, Dewan Perwakilan Rakyat Daerah Provinsi, dan Dewan Perwakilan Rakyat Daerah Kabupaten/Kota Tahun 2019, sepanjang pada Diktum kedua huruf b yang pada pokoknya menetapkan Partai Keadilan dan Persatuan Indonesia tidak memenuhi syarat sebagai peserta Pemilihan Umum Anggota Dewan Perwakilan Rakyat, Dewan Perwakilan Rakyat Daerah Provinsi, dan Dewan Perwakilan Rakyat Daerah Kabupaten/ Kota Tahun 2019;

4. Memerintahkan KPU RI untuk menerbitkan Surat Keputusan tentang penetapan PKP Indonesia cq. Partai Keadilan dan Persatuan Indonesia sebagai Partai Politik Peserta Pemilihan Umum Anggota Dewan Perwakilan Rakyat, Dewan Perwakilan Rakyat Daerah Provinsi, dan Dewan Perwakilan Rakyat Daerah Kabupaten / Kota Tahun 2019;

5. Menghukum KPU RI untuk membayar seluruh biaya yang timbul dalam perkara ini sejumlah Rp. 1.186.000,- (Satu Juta Seratus Delapan Puluh Enam Ribu Rupiah);

\section{Hasil Analisa}

Ditinjau dari sudut pandang normatif, sahnya suatu Keputusan Tata Usaha Negara didasarkan pada pasal 53 ayat (2) Undang Undang Nomor 9 Tahun 2004 tentang Peradilan Tata Usaha Negara yakni Keputusan Tata Usaha Negara sesuai dengan peraturan perundang undangan yang berlaku dan sesuai dengan Asas Asas Umum Pemerintahan Yang Baik.

1. Keputusan Tata Usaha Negara sesuai dengan peraturan perundang undangan yang berlaku Penjelasan pasal 53 ayat (2) Undang Undang Nomor 9 Tahun 2004 tentang Peradilan Tata Usaha Negara dijelaskan bahwa kesesuaian Keputusan Tata Usaha Negara dengan peraturan perundang-undangan meliputi:

a) Kesesuaian dengan peraturan perundang undangan yang bersifat formal/prosedural. 
b) Kesesuaian dengan peraturan perundang undangan yang bersifat material/substansi.

c) Dikeluarkan oleh badan atau pejabat yang berwenang.

2. Keputusan Tata Usaha Negara sesuai dengan Asas Asas Umum Pemerintahan Yang Baik Pasal 53 ayat (2) Undang Undang Nomor 9 Tahun 2004 tentang Peradilan Tata Usaha Negara, memuat ketentuan bahwa yang dimaksudkan dengan asas asas umum pemerintahan yang baik merupakan asas asas umum penyelenggara negara sebagaimana yang dimaksudkan dalam pasal 3 Undang Undang Nomor 28 Tahun 1999 tentang Pemerintahan Negara yang Bersih dan Bebas dari Korupsi, Kolusi dan Nepotisme, yang meliputi

a) Asas kepastian hukum Asas dalam negara hukum yang mengutamakan landasan peraturan perundang undangan yang berlaku, keputusan dan keadilan dalam setiap kebijakan.

b) Asas tertib penyelenggaraan negara Asas yang menjadi landasan keteraturan, keserasian dan keseimbangan dalam pengendalian penyelenggaraan negara.

c) Asas keterbukaan Asas yang membuka diri pada hak-hak masyarakat untuk memperoleh informasi yang benar, jujur dan tidak diskriminatif tentang penyelenggara negara dengan tetap memperhatikan perlindungan atas hak-hak atas pribadi, golongan dan rahasia negara.

d) Asas proporsionalitas Asas yang mengutamakan keseimbangan antara hak dan kewajiban penyelenggara negara.

e) Asas profesionalitas xxxvii Asas yang mengutamakan keahlian yang berlandaskan kode etik dan ketentuan peraturan perundang-undangan yang berlaku.

f) Asas akuntabilitas Asas yang menentukan bahwa setiap kegiatan dan hasil akhir dari kegiatan penyelenggara negara harus dapat dipertanggungjawabkan kepada masyarakat atau rakyat sebagai pemegang kedaulatan tertinggi negara sesuai dengan ketentuan peraturan perundang undangan yang berlaku.

Terdapat satu asas lagi yang tidak diatur dalam pasal 3 Undang Undang Nomor 28 Tahun 1999 tentang Pemerintahan Negara yang Bersih dan Bebas dari Korupsi, Kolusi dan Nepotisme namun diatur dalam penjelasan pasal 53 ayat (2) Undang Undang Nomor 9 Tahun 2004 tentang Peradilan Tata Usaha Negara yakni asas kepentingan umum. Asas ini mengandung muatan mendahulukan kesejahteraan umum dengan cara yang aspiratif, akomodatif dan selektif.

\section{Penerapan Asas Tidak Berlaku Surut \& Asas Pengharapan Yang Wajar}

Bahwa KPU telah nyata melanggar asas-asas penyelenggaran pemerintahan yang baik. Dalam hal ini yang pertama melalui putusan Mahkamah Konstitusi RI Nomor: 53/PUUXV/2017 tertanggal 11 Januari 2018, yang pada pokoknya menguji/memutuskan yaitu dalil Pemohon agar frasa "telah ditetapkan/" dalam Pasal 173 ayat (1) dan seluruh norma dalam Pasal 173 ayat (3) UU Pemilu dinyatakan bertentangan dengan UUD 1945 dan tidak mempunyai kekuatan hukum mengikat adalah beralasan menurut hukum, maka terhadap Putusan Mahkamah Konstitusi tersebut dimaknai bahwa seluruh Partai Politik Calon Peserta Pemilu 2019 baik yang 
lama maupun yang baru harus dilakukan Verifikasi dikarenakan Putusan Mahkamah Konstitusi tersebut bersifat final dan mengikat (final and binding).

Hal tersebut berarti putusan MK ini wajib untuk segera dipatuhi dan diberlakukan karena kekuatan hukum yang final dan mengikat kepada seluruh warga negara Indonesia, namun pemberlakuannya tidak dapat berlaku surut atas kondisi dari PKP Indonesia yang sebelumnya telah mendapatkan penyataan resmi bahwa telah lolos penelitian administrasi untuk selanjutnya dilakukan verifikasi faktual berdasarkan Berita Acara Hasil Akhir Penelitian Administrasi Dokumen Persyaratan Partai Politik Calon Peserta Pemilu Tahun 2019 Nomor: 92/PL.01.1BA/03/KPU/XII/2017 tertanggal 22 Desember 2017 sehingga sebagaimana diatur dalam ketentuan Pasal 47 Undang-Undang Nomor 24 Tahun 2003 Tentang Mahkamah Konstitusi dan juga di dalam Putusan Mahkamah Kostitusi tersebut tidak memuat frasa "retroaktif" atau berlaku surut.

Hal ini jelas tidak dapat menghilangkan hak konstitusional PKP Indonesia untuk menjadi peserta pemilu dengan keluarnya putusan MK yang terbit setelah kondisi PKP lolos peneliatan administrasi. Dengan demikian bahwa tindakan KPU RI yaitu menerbitkan Peraturan KPU terkait pemberlakuan verifikasi terhadap seluruh Partai Politik Calon Peserta Pemilu 2019 sudah sesuai dengan asas kepastian hukum khususnya terhadap satu putusan, namun KPU RI harus menyadari dan mempunyai konsekuensi hukum terhadap produk atau tindakan hukum yang telah atau terlanjur diterbitkan.

Hal ini yaitu Berita Acara Hasil Akhir Penelitian Administrasi Dokumen Persyaratan Partai Politik Calon Peserta Pemilu 2019 Nomor: 92/PL.01.1-BA/03/KPU/XII/2017 tertanggal 22 Desember 2017 dan Surat Keputusan Komisi Pemilihan Umum Republik Indonesia Nomor: 232/PL.01.1-Kpt/03/KPU/XII/2017 Tertanggal 22 Desember 2017 Tentang Perubahan Atas Keputusan Komisi Pemilihan Umum Nomor: 227/PL.01.1-Kpt/03/KPU/XII/2017 Tentang Kedudukan Partai Politik Peserta Pemilu Tahun 2014 Pada Daerah Otonom Baru Dalam Pemenuhan Persyaratan Partai Politik Peserta Pemilu 2019.

Oleh karena tidak ada 1 (satu) bukti pun dalam persidangan yang menyatakan bahwa sampai dengan terbitnya objek sengketa kedua produk/tindakan hukum administrasi KPU RI tersebut telah dinyatakan batal oleh Pengadilan atau dinyatakan tidak berlaku atau dicabut oleh KPU RI sendiri sesuai Asas Contrarius Actus yaitu asas ini mempunyai makna Badan atau Pejabat Tata Usaha Negara yang menerbitkan keputusan Tata Usaha Negara dengan sendirinya juga berwenang untuk membatalkannya, dan juga tidak mencantumkannya kedua produk / tindakan hukum administrasi KPU RI tersebut adalah tindakan yang tidak konsisten dan melanggar ketentuan Pasal 3 huruf d dan e yang pada pokoknya berbunyi Penyelenggara Pemilu atau KPU RI harus memenuhi prinsip berkepastian hukum dan tertib, selain itu juga KPU RI melanggar asas kepercayaan dan menanggapi pengharapan yang wajar, dimana asas ini menghendaki agar setiap tindakan yang dilakukan oleh pemerintah harus menimbulkan harapanharapan bagi warga negara. Jika suatu harapan sudah terlanjur diberikan kepada warga negara tidak boleh ditarik kembali meskipun tidak menguntungkan bagi pemerintah. 


\section{Pelanggaran Terhadap Asas Kecermatan}

Berita Acara Rekapitulasi Nasional Hasil Penelitian Administrasi Dan Verifikasi Kepengurusan, Keterwakilan Perempuan, Domisili Kantor Keanggotaan Partai Politik Calon Peserta Pemilu Nomor: 21/PL.01.1-BA/KPU/II/2018 tertanggal 17 Februari 2018, bahwa di dalam Berita acara tersebut khususnya dalam lampiran untuk Provinsi Jawa Timur yaitu pada Kabupaten Jombang dalam kolom status tertulis TMS atau Tidak Memenuhi Syarat, hal ini berbanding terbalik atau tidak sama dengan fakta hukum yang sebenarnya yaitu dalam Berita Acara Rekapitulasi hasil Penelitian Administrasi dan verifikasi Faktual kepengurusan, keterwakilan perempuan, domisili kantor, dan keanggotaan partai politik calon peserta pemilu Provinsi Jawa Timur Kabupaten Jombang Nomor: 15/PL.03.6- BA/02/KPU /II/2018 beserta lampiran Model F.A.REKAP.KPU.KAB/KOTAPARPOL, dimana dalam Berita Acara tersebut yang diterbitkan berdasarkan Berita Acara sebelumnya tertulis dengan jelas dan tegas bahwa PKP Indonesia Memenuhi Syarat secara keseluruhan di Kabupaten Jombang.

Berita Acara Nomor: 18/PL.01.1-BA/3203/KPUKab/II/2018 Berita Acara rekapitulasi hasil penelitian administrasi dan verifikasi kepengurusan, keterwakilan perempuan, domisili kantor, dan keanggotaan partai politik calon peserta pemilu yang pada pokoknya telah menyatakan secara keseluruhan bahwa PKP Indonesia di kabupaten Cianjur Memenuhi Syarat dan kemudian dalam Berita Acara Nomor: 19/PL.01.1-BA/3203/KPU-Kab/II/2018 Tentang Ralat rekapitulasi hasil administrasi dan verifikasi keanggotaan partai politik calon peserta pemilu untuk Partai Keadilan dan Persatuan Indonesia (PKP Indonesia), KPU RI mengubah/meralat menjadi Tidak memenuhi Syarat dan menyerahkannya kepada PKP Indonesia yang diterima pada tanggal 13 Februari 2018.

Perubahan dari yang sebelumnya dinyatakan memenuhi syarat menjadi tidak memenuhi syarat jelas melanggar asas kecermatan yang seharusnya dilakukan KPU RI sebagai Lembaga Negara. Sehingga dengan ini penulis setuju terhadap Putusan PTUN yang memenangkan PKP Indonesia atas gugatannya dalam pengadilan PTUN No. 56/G/SPPU/2018/PTUN-JKT.

\section{PENUTUP}

1. Putusan PTUN No. 56/G/SPPU/2018/PTUN-JKT memberikan kepastian hukum kepada PKP Indonesia atas hak konstitusionalnya yang semula dan sebelumnya sebagai partai politik peserta pemilu dan telah ikut serta dalam kegiatan pemilu di Indonesia. Dengan putusan ini maka hal yang mencegah PKP Indonesia untuk ikut serta dalam pemilu sudah tidak ada lagi, sebab Putusan PTUN jelas mengabulkan permohonan PKP untuk seluruhnya bahwa yang bersangkutan telah memperoleh pemulihan akibat pelanggaran administrasi yang dilakukan KPU RI terhadap Partai politiknya.

2. Pertimbangan majelis hakim terhadap PKP Indonesia adalah dengan jelas memberitahukan kepada KPU untuk tidak serta merta memberlakukan secara teknis dan hierarkis keputusan MK Nomor: 53/PUU-XV/2017 tertanggal 11 Januari 2018 yang telah final dan binding. Sebab sebelumnya adanya putusan MK tersebut KPU RI telah menerbitkan penyataan resmi bahwa telah lolos penelitian administrasi untuk selanjutnya dilakukan verifikasi faktual 
berdasarkan Berita Acara Hasil Akhir Penelitian Administrasi Dokumen Persyaratan Partai Politik Calon Peserta Pemilu Tahun 2019 Nomor: 92/PL.01.1-BA/03/KPU/XII/2017 tertanggal 22 Desember 2017 sehingga sebagaimana diatur dalam ketentuan Pasal 47 Undang-Undang Nomor 24 Tahun 2003 Tentang Mahkamah Konstitusi dan juga di dalam Putusan Mahkamah Kostitusi tersebut tidak memuat frasa "retroaktif" atau berlaku surut.

\section{DAFTAR PUSTAKA}

Abdulah, Rozzali. 2005. hukum acara peradilan tata usaha Negara, Raja grafindo persada. Jakarta.

Sjachran Basah, Eksistensi dan Tolok Ukur Badan Peradilan Administrasi di Indonesia, Alumni, Bandung, 1985.

Ridwan HR, Hukum administrasi Negara, edisi revisi, Rajawali Pers. 2011.

Tjandra, W. Riawan, 2005, Hukum Acara Peradilan Tata Usaha Negara, Edisi Revisi, Yogyakarta: Universitas Atma Jaya Yogyakarta.

Tjandra, W. Riawan, 2009, Peradilan Tata Usaha Negara (PTUN): Mendorong Terwujudnya Pemerintah yang Bersih dan Berwibawa, Yogyakarta: Universitas Atma Jaya.

Kuntjoro Purbopranoto, Beberapa catatan Hukum Tata Pemerintahan dan Peradilan Administrasi Negara, cet. 2 (Bandung: Alumni, 1978).

Undang-Undang No. 5 Tahun 1986 jo. UU No. 9 Tahun 2004 Jo. UU No. 51 Tahun 2009 tentang Peradilan Tata Usaha Negara.

Undang-Undang Nomor 7 Tahun 2017 Tentang Pemilihan Umum,

Undang-Undang Nomor 5 tahun 1986 sebagaimana telah diubah dengan Undang-Undang Nomor 9 Tahun 2004 dan UndangUndang Nomor 51 Tahun 2009,

Peraturan Komisi Pemilihan Umum Republik Indonesia Nomor 5 Tahun 2018 Tentang Perubahan atas Peraturan Komisi Pemilihan Umum Nomor 7 Tahun 2017 Tentang Tahapan, Program, Dan Jadwal Penyelenggaraan Pemilihan Umum Tahun 2019,

Peraturan Komisi Pemilihan Umum Republik Indonesia Nomor 6 Tahun 2018 Tentang Pendaftaran, Verifikasi, Dan Penetapan Partai Politik Peserta Pemilihan Umum Anggota Dewan Perwakilan Rakyat Dan Dewan Perwakilan Rakyat Daerah

Peraturan Mahkamah Agung Republik Indonesia Nomor 5 Tahun 2017 Tentang Tata Cara Penyelesaian Sengketa Proses Pemilihan Umum Di Pengadilan Tata Usaha Negara.

Putusan PTUN No. 56/G/SPPU/2018/PTUN-JKT

https://http716.wordpress.com/2016/10/28/hukum-ptun-pengertian-asas-asas-dan-perbedaanantara-acara-ptun-dengan-acara-perdata/ 